\title{
Social Media Usage Purposes of Farmers in Selçuklu District of Konya Province
}

\author{
Aysun Yener Ögürr,a,", Türkşan Karatekin²,b, Fatma Doğançukuru ${ }^{3, c}$ \\ ${ }^{1}$ Department of Agricultural Economics, Faculty of Agriculture Selçuk University, 42130 Konya, Turkey, \\ ${ }^{2}$ Ministry of Agriculture and Forestry, 06800 Ankara, Turkey \\ ${ }^{3}$ Selçuklu District Directorate of Agriculture and Forestry, 42250 Konya, Turkey
}

\section{A R T I C L E IN F O A B S T R A C T}

Research Article

The aim of this study is to determine the purpose of social media usage of farmers in Selçuklu district of Konya province. The sample volume was determined as 80 according to the stratified random sampling method, with a 95\% confidence interval and with a 5\% margin of error. Factor analysis was conducted to determine the farmers' social media usage purposes. Factor analysis was conducted on 19 independent variables and 3 independent variables were identified to determine the reasons for using social media. These variables are called professional development, socialization, and communication. The relationship between professional development, socialization, and communication variables and social media platforms was determined by linear regression analysis. For platforms used for socialization purposes, it was found that Facebook was statistically significant at $1 \%$ and Instagram was $5 \%$. According to the regression analysis, platforms used for vocational development purposes, it was found that WhatsApp was statistically significant at $1 \%$ and YouTube was 5\%. In social media, training, extension, projects, and promotions should be more widely supported in order to support the professional training of enterprises. In addition, pieces of training should be provided for enterprises to use social media platforms more effectively.

\begin{tabular}{l|l} 
Information source & $\begin{array}{l}\text { platforms used for vocational development purposes, it was found that WhatsApp was statistically } \\
\text { Internet }\end{array}$ \\
Sonnificant at $1 \%$ and YouTube was $5 \%$. In social media, training, extension, projects, and \\
promotions should be more widely supported in order to support the professional training of \\
Regression analysis \\
Farmers
\end{tabular}$\quad \begin{aligned} & \text { enterprises. In addition, pieces of training should be provided for enterprises to use social media } \\
& \text { platforms more effectively. }\end{aligned}$

\section{Introduction}

A common language to explain and analyze examples of Information and Communication Technologies (ICT)mediated learning networks is useful for developing network-based learning in agricultural extension and transferring information between examples (Carvalho and Goodyear 2014; Goodyear and Carvalho 2013). It is considered to consist of ICT learners, participants, educators and learning resources (Banks et al., 2003; Dirckinck-Holmfeld et al., 2009). Educators are defined as actors in the network with experiences valued by the community, while learners are people who have the motivation to learn from those experiences. Thus, in different contexts, the roles of learners and educators may be interchangeable. Resources are defined as non-human elements that contribute to the co-creation of information within the network (Kelly et al., 2017). Social media is a brand-new communication tool of the 21 st century. Giving users a choice, it is rather distinctive from traditional media tools such as newspapers, radio and television. In the publication prepared by the American non-governmental organization "Animal Agriculture Alliance", the definition of social media is as follows: "social media is a way of building relationships between people, sharing information and connecting with hard-to-reach people (Anonymous, 2019a). In social media, users can create groups, pages, channels as well as executing numerous functions all together such as generating, deriving, directing, marketing, etc. Social media is a sustainable learning and sharing platform that is unique, fast, effective, economical all at the same time. More than half of the world's population is under the influence of the gravitational power of the internet. Four of every ten people are social media users now (Anonymous, 2019b). There exists a parallelism between smartphone users and social media usage. The number of active monthly users on the world's most popular social media platforms has exceeded 2 billion (Statista, 2019). Social media has become an important part of the reputation and perception management of brands in the business world. Social media investments have become one of the indispensable topics of sales and marketing 
budgets. Many companies allocate $35-45 \%$ of their annual marketing budget to digital marketing and $15-25 \%$ of this budget goes to social media platforms (Preston, 2018). In the scale of Turkey, especially the use of social media is swiftly gaining popularity amongst young people. The compatibility of the youngest part of the population with the most dynamic area of communication is increasing day by day. Considering the objectives of internet use, social media preferences such as creating profiles on social media, messaging and sharing photos, etc., rank first with a rate of $84.1 \%$ (TURKSTAT, 2019a). 64\% of Turkey's total population uses social media. The time spent on social media is an average of 2 hours and 51 minutes per day. (Digital, 2020). Overall, it can be said that social media is at the very center of our lives.

Observing social media on a commercial scale, it can be seen that e-trade volume in Turkey in 2017 reached 42.2 billion growing $37 \%$ compared to 2016 . The rate of online transactions in the total retail market has increased up to $4.1 \%$, while the average of developing countries is $4.8 \%$ (TÜBİSAD, 2018). According to the digital 2019 research, 2.8 billion people annually purchase products or services through e-trade channels, corresponding to $37 \%$ of the total population. While this group brings in the e-trade market $\$$ 1.7 trillion annually, the per capita expenditure is $\$ 634$. Users spend the most on travel and fashion-beauty titles in the e-trade market. The share of Turkey's e-trade market is relatively still quite small (Anonymous, 2019a). As can be seen, social media has been rapidly integrating into sectors by raising both the volume of individuals' social life and their share in trade. As well as bringing new dimensions to information and communication technologies, social media has had an impact on the agricultural sector as well as on almost every business line. This is because the scope and dynamic nature of social media facilitate access to information. In the agricultural sector, social media comes to the fore in rural development, agricultural production, agricultural marketing, access to information, etc. Social media enhances agricultural communication and implements an innovative communication environment to agricultural stakeholders by promoting the farmer and industry network. It is a potent, useful and controversial tool that connects billions of people globally (Hawley et al., 2018). Farmers use social media for its capacity to bring together all the stakeholders of the agricultural sector (farmers, experts, enterprises and scientists). As well as being used for personal purposes, they tell their own success or failure stories on social media. Up-to-date information on agricultural production is shared (Balkrishna \& Deshmukh, 2017). It can be commented that social media has become the most prominent tool for following innovations in agriculture.

Konya city constitutes a great potential for Turkey's agricultural production. Konya, with its $40.838 \mathrm{~km} 2$ surface area is the largest landholdings in Turkey. The city ranks first in wheat, sugar beet, barley, oilseed and cultivation of silage corn, alfalfa (green grass), dry beans, carrots, cherries, apple, meat, milk and egg production in Turkey. Selçuklu is the most populous district of Konya province in terms of population density. According to 2017 data, the population density of Konya province is 57 persons $/ \mathrm{km}^{2}$ and the population density of Selçuklu district is 332 persons $/ \mathrm{km}^{2}$ (Anonymous, 2019c) The average for
Turkey is 107 persons $/ \mathrm{km}^{2}$ (TURKSTAT, 2019b). The population density of the Selçuklu district is higher than the Turkey average. Therefore, the research was conducted in the Selcuklu district of Konya, one of the most important agricultural production centers in Turkey, to ascertain the social media usage aims of farmers. With the study, the social media usage purposes of the farmers involved in agricultural production were determined. In the literature, there are studies on the social media usage purposes of farmers (Thakur et al., 2017; Soylu et al., 2016; Han et al., 2021; Kanjina, 2021; Ofori \& El-Gayar, 2019; Riley \& Robertson, 2021). However, no study was found for Konya province. For this reason, the study has been carried out and its results will be beneficial to the research area.

\section{Material and Method}

Agricultural enterprises operating in Konya province created the main framework of the study. In the study, Selçuklu district was selected according to the purposeful sampling method. From this mainframe, the sample volume was executed according to the stratified random sampling method. The method was used in the study to raise the accuracy of the findings collected from the enterprises and to ensure that the different sections in the population were adequately represented (Güneş \& Arıkan, 1985).

The number of samples in the study was calculated according to the formula below (Aoyama, 1954; Yamane, 1967). The sample volume was determined to be 80 with a $95 \%$ confidence interval and a $5 \%$ margin of error.

$$
\begin{aligned}
& n=\frac{\sum\left(\mathrm{N}_{\mathrm{h}} \mathrm{S}_{\mathrm{h}}\right)^{2}}{\mathrm{~N} 2 \mathrm{D} 2+\Sigma \mathrm{Nh} . \mathrm{S} 2 \mathrm{~h}} \\
& \mathrm{D}^{2}=\mathrm{d}^{2} / \mathrm{z}^{2}
\end{aligned}
$$

Where;

$\mathrm{n} \quad=$ Sampling size

$\mathrm{N}$ = Number of total holdings in population

$\mathrm{d}=$ Allowed error rate from the main mass average value

$\mathrm{t}=$ Standard normal distribution value

$\mathrm{N}_{\mathrm{h}}=\mathrm{h}$. Number of the population in $\mathrm{h}$

$\mathrm{S}_{\mathrm{h}}{ }^{2}=$ is the variance of $\mathrm{h}$

$\mathrm{D}^{2}=\mathrm{d}^{2} / \mathrm{z}^{2}$

$\mathrm{z} \quad=$ Is the reliability coefficient (1.96 which represents $95 \%$ confidence).

Data of the 80 surveys conducted in the research area was evaluated according to the enterprise sizes formed with the suckled cow number 1-50 da (6 enterprises), 51-150 da (20 enterprises) and 151-550 da (40 enterprises), 551 and more (14 enterprises).

The distribution of sample volume according to enterprise groups is given in Table 1.

Table 1. Distribution of enterprises by land size (sample volume)

\begin{tabular}{l|c}
\hline \multicolumn{1}{c|}{ Enterprise Size Groups } & Sample Volume (pcs) \\
\hline $1-50$ & 6 \\
$51-150$ & 20 \\
$151-550$ & 40 \\
$551-+$ & 14 \\
Total & 80 \\
\hline
\end{tabular}


The age, education, income, land assets, number of animals, products, social media perception and social media platforms are given with simple percentage calculations. Information sources used in enterprises, social media usage frequencies and social media usage frequencies in agricultural issues are given according to 5Point Likert Scale. Likert scale is one of the attitude scale scales and is involved in regulated scales.

The fundamental approach in the Likert scale is to give judgments about the subject under investigation and to evaluate and grade the concentration on these judgments. For this view, the factor is determined first, and each factor is turned into a question according to the conditions of the scale. Then, for these questions, scale scores that indicate the participation degree of the participants in the survey are built. Individuals whose attitude analysis will be made determine their own scores according to their degree of participation. The scale value of the person is found with the scores calculated for the degree of participation. With this value gained, the factors that circumscribe an individual's attitude or behavior towards an event are graded (Erdoğan, 1997). The survey study was conducted in 2019 and face-to-face.

In the study, linear regression analysis was carried out to ascertain the social media usage purposes of the farmers. Linear regression analysis measures the dependency of a single dependent variable with more than one explanatory variable. The mean of the first (population) is the model that foretells the latter in terms of known or unchanged values (in repeated samples). The linear regression model is examined by correlation analysis whether there is a relationship between dependent and independent variables. The correlation coefficient utilizes values between -1 and +1 and is denoted by $r .+1$ indicates that there is a strong positive relationship, 0 indicates that there is no relationship, while -1 symbolizes that there is a strong opposite relationship. To test the significance and appropriateness of the variables obtained in the regression analysis; the t-test value and the determination coefficient are used depending on the correlation coefficient. The determination coefficient of the variables shows the strength of the interaction and the " $\mathrm{t}$ " test shows the interaction between dependent and independent variables. The determination coefficient is the square of the correlation coefficient $\left(\mathrm{R}^{2}\right)$. The closer the determination coefficient is to 1 , the higher the significance of the regression equation. Projection equations consist of a dependent variable and the independent variables managing this variable. Besides, these equations are established by the least-squares method (Gujarati, 2009; Kalayc1, 2014). The dependent and independent variables used in the study are given below.

$$
Y=\beta 0+\beta_{1} X_{1}+\beta_{2} X_{2}+\beta_{3} X_{3}+\beta_{4} X_{4}+\beta_{5} X_{5}+\beta_{6} X_{6}
$$

\section{Where:}

$\mathrm{Y}=$ Social Media Usage Purposes of Farmers

$\mathrm{Y}_{1}=$ : Use of social media for professional development

$\mathrm{Y}_{2}=$ Use of social media for socializing).

$\beta 0=$ Constant Value

$\mathrm{X}_{1}=$ WhatsApp

$\mathrm{X}_{2}=$ Facebook

$\mathrm{X}_{3}=$ YouTube

$\mathrm{X}_{4} \quad=$ Instagram

$\mathrm{X}_{5}=$ Twitter
In the regression model, factor loads obtained as a result of factor analysis were used as dependent variables. As a result of factor analysis, 3 factors were determined. A model was established for 2 of these factors and the model was found to be significant. In the 1st model, the dependent variable is Use of social media for professional development, and in the 2nd model, the dependent variable is Use of social media for socializing. $\mathrm{R}^{2}$ value; It was determined as $47.20 \mathrm{in}$ model 1 and 28.3 in model 2. Studies in the literature were examined and $\mathrm{R}^{2}$ values were found to be appropriate (Tiraieyari et al., 2010; Below et al., 2012; Danso-Abbeam et al., 2018; Harniati \& Anwarudin, 2018; Pradhan et al., 2020; Kassem et al., 2021).

Factor analysis was used for the classification of independent variables. Factor analysis is a multivariate statistical technique that takes a small number of unrelated variables by bringing together the related variables of a large number of data. In factor analysis, a large number of observed variables are explained by a reduced number of factors. However, correlations between these variables are taken into consideration (Johnson \& Wichern, 1992; Kalayc1, 2014). The factor analysis model has many methods, the most common of which are "common factor analysis" and "component factor analysis". The choice of factor model depends on the purpose of the research. In the mathematical model of factor analysis, the standardized variable $i$ is as follows.

$$
X i=A_{i 1} F_{1}+A_{i 2} F_{2}+\ldots . .+A_{i n} F_{k}+U
$$

Fs in the equation refer to general factors; $U$ for Unique factor and A are constants combining $\mathrm{k}$ factors. It is trusted that unique factors have no correlation with each other and with general factors (Gül, 1995). Factors are derived from observed variables and can be estimated as their linear components. General estimation equality of $\mathrm{Fj}$, which is the Jth factor:

$$
F j=\sum W_{j i} X_{i}=W_{j 1} X_{1}+W_{j 2} X_{2}+\ldots \ldots+W_{j k} X_{k},
$$

Score numbers and $\mathrm{p}$ indicate the number of variables. Until the factor analysis results were obtained, many different alternatives were tried and as a result of the factor analysis started with approximately 19 variables, 3 variables with a high degree of commonality were collected. The 3 independent variables produced as a result of factor analysis were named professional development, socialization and communication. The power of 3 independent variables to represent all variables is $79.364 \%$. Kaise-Meyer-Olkin sampling adequacy criterion statistic calculated over the analysis data was found to be above 0.5 (Tamuliene, 2014; Raju, 2016; Raju, 2017; Kwon et al., 2018). In order to test the applicability of the factor analysis method in the study, the partnership factor was taken into consideration. The partnership factor, one of the effective factors in defining the variables, shows the representation ability of the variables. The closer this value is to 1 , the more accurate and healthier the choice of variables is accepted (Kalayc1, 2014). In addition, reliability analysis was performed in the study, and the Cronbach-Alpha value was checked. It was 0.969. The alpha coefficient is also a measure of internal consistency. It measures how consistent the items in the scale are with 
each other whether they form a whole or not (Cronbach, 1951; Last, 2001; Dawson \& Trap 2004). It ranges from 0 to 1 , and the closer to 1 , the greater the reliability. In the study, the Cronbach-Alpha value was 0.969.

\section{Research Findings and Discussion}

The enterprises subject to the study were assessed in terms of demographic characteristics such as age, education, number of individuals in the household, income level, production activities and production patterns. Among the age groups, the age group between 15-49, defined as the active population, has the highest rate $(58.10 \%)$. The average of enterprises over the age of 50 is in second place with $31.43 \%$. It has been concluded that the rural population is gradually getting older and the young population has turned to non-agricultural areas as a result of the deepening of the structural problems of the agricultural sector. The fact that $89 \%$ of the enterprises aged 35 and over in their study on the determination of the sources of information used by the enterprises in agricultural activities in Kahramanmaraş is an indication that the aging process in the rural area started long ago (Boz et al., 2004). Considering the educational status of the enterprises, $58.19 \%$ of the population are primary school graduates, $21.40 \%$ are high school graduates, $13.30 \%$ are secondary school graduates while $7.02 \%$ are university graduates. Similarly, in a study on computer and internet use in rural agricultural development in the city of Tokat, it was reported that primary school graduates are in the majority and university graduates are in the minority (Büyükbay \& Gündüz, 2011). Considering the income status of the enterprises in the research area, $12.73 \%$ of them gets $1001-2000$ TL per month, while $32.73 \%$ has 2001-3000 TL, 27.27\% gets 3.001-4.000 TL, 5.45\% with 4001- -5000 TL and $21.82 \%$ has a monthly income of 5.000-+ TL (Table 2). Looking at the equivalent household

Table 2. Socio-economic status of enterprises disposable income distribution, the average monthly income in rural areas is 780 TL (TURKSTAT, 2019c).

The average land assets in the surveyed enterprises are 343.11 decares. In terms of crop production, $49.11 \%$ of the land is barley, $20.67 \%$ wheat, $8.89 \%$ grain corn, $7.74 \%$ sugar beet, $4.35 \%$ sunflower, $3.33 \%$ clover, $1.61 \%$ corn for silage, $1.19 \%$ oats, $1.19 \%$ beans, $0.77 \%$ canola, $0.55 \%$ chickpeas, $0.24 \%$ Hungarian vetch, 0.22 Lenox, $0.05 \%$ potato, $0.09 \%$ mixed fruit and vegetable production is carried out. $5.43 \%$ of the animal assets in the enterprises are sheep, $22.77 \%$ cow, $9.61 \%$ lamb, $5.91 \%$ goat, $5.00 \%$ heifer, $2.70 \%$ calf and $1.58 \%$ calf.

The sources of information used in the enterprises analyzed in the research field are given in Table 3. According to the sources of information used, television programs take the first place while the internet ranks second. In a study carried out in 2019, it was reported that farmers benefited from the internet in accessing agricultural information (Everest et al., 2019). Family members are among the resources sometimes referenced. In a study conducted in 2004, on the other hand, family members and neighbors are in the first place in almost every heading as an agricultural information source (Boz et al., 2004). In a similar study, the use of printed materials and the internet as sources of information was found to be very low due to the low education level of the farmers (Naveed et al., 2012). Agricultural use of electronic media for information was not encouraging. Television, mobile phone, radio and telephone were followed by the most used information sources (Khan et al., 2010).

$91 \%$ of the enterprises partaking in the research own smartphones and $86 \%$ of this population spends more than 4 hours a week on the internet. The findings gained in the field of research explicate that the time enterprises spend on the internet and the time they spend on social media are almost identical. The predictions are that social media will boost its share in internet usage in the near future (Tekbaş, 2014).

\begin{tabular}{|ccccc}
\hline 2. Group & 2. Group & 3. Group & 4. Group & Enterprises Average \\
\hline Number Percent (\%) Number Percent (\%) Number Percent (\%) Number Percent (\%) Number Percent (\%)
\end{tabular}

\begin{tabular}{|c|c|c|c|c|c|c|c|c|c|c|}
\hline \multicolumn{11}{|c|}{ Age Groups } \\
\hline $0-6$ & 0.33 & 7.69 & 0.15 & 3.90 & 0.10 & 2.48 & 0 & 0 & 0.11 & 2.86 \\
\hline $7-14$ & 0.33 & 7.69 & 0.25 & 6.49 & 0.35 & 8.70 & 0.21 & 5.88 & 0.30 & 7.62 \\
\hline $15-49$ & 2.83 & 65.38 & 1.75 & 45.45 & 2.53 & 62.73 & 2.14 & 58.82 & 2.29 & 58.10 \\
\hline $50-+$ & 0.83 & 19.23 & 1.70 & 44.16 & 1.05 & 26.09 & 1.29 & 35.29 & 1.24 & 31.43 \\
\hline Total & 4.33 & 100 & 3.85 & 100 & 4.03 & 100 & 3.64 & 100 & 3.94 & 100 \\
\hline \multicolumn{11}{|c|}{ Educational status } \\
\hline Primary school & 1.67 & 58.82 & 2.50 & 68.49 & 2.18 & 55.06 & 1.93 & 52.94 & 2.18 & 58.19 \\
\hline Middle School & 0.33 & 11.76 & 0.15 & 4.11 & 0.63 & 15.82 & 0.71 & 19.61 & 0.50 & 13.38 \\
\hline High school & 0.17 & 5.88 & 0.65 & 17.81 & 1.05 & 26.58 & 0.57 & 15.69 & 0.80 & 21.40 \\
\hline University & 0.67 & 23.53 & 0.35 & 9.59 & 0.10 & 2.53 & 0.43 & 11.76 & 0.26 & 7.02 \\
\hline Total & 2.83 & 100 & 3.65 & 100 & 3.95 & 100 & 3.64 & 100 & 3.74 & 100 \\
\hline \multicolumn{11}{|c|}{ İncome status } \\
\hline $0-1000$ & 0 & 0 & 0 & 0 & 0 & 0 & 0 & 0 & 0 & 0 \\
\hline $1001-2000$ & 0.17 & 16.67 & 0.20 & 20 & 0.05 & 5.00 & 0.07 & 7.14 & 0.10 & 10 \\
\hline 2001-3000 & 0.67 & 66.67 & 0.40 & 40 & 0.20 & 20 & 0.07 & 7.14 & 0.26 & 26.25 \\
\hline $3001-4000$ & 0.17 & 16.67 & 0.30 & 30 & 0.33 & 32.50 & 0.21 & 21.43 & 0.29 & 28.75 \\
\hline $4001-5000$ & 0 & 0 & 0.05 & 5.00 & 0.20 & 20 & 0.07 & 7.14 & 0.13 & 12.50 \\
\hline $5000-+$ & 0 & 0 & 0.05 & 5.00 & 0.23 & 22.50 & 0.57 & 57.14 & 0.23 & 22.50 \\
\hline Total & 1 & 100 & 1 & 100 & 1 & 100 & 1 & 100 & 1 & 100 \\
\hline
\end{tabular}


Table 3. Agricultural information sources used in enterprises

\begin{tabular}{l|c}
\hline \multicolumn{1}{c|}{ Agricultural Information Resources Used in Enterprises } & Number $^{*}$ \\
\hline TV show & 3.95 \\
Internet & 3.91 \\
Family members & 3.28 \\
Neighboring enterprises & 2.89 \\
Agriculture District / Provincial Directorate staff & 2.49 \\
Dealers selling pesticides & 2,43 \\
Self-employed veterinarian & 2.08 \\
Agricultural tool machine dealer & 2.06 \\
Agricultural magazines, magazines, brochures etc. & 1.89 \\
Chamber of Agriculture & 1.51 \\
Private entity (trader) purchasing product & 1.50 \\
Faculty of Agriculture staff & 1.36 \\
Animal exchange & 1.36 \\
Government agency purchasing the product & 1.16 \\
Video, DVD, VCD etc. representation & 1.11 \\
Newspaper article & 1.09 \\
Radio show & 1.05
\end{tabular}

*(5: always, 4: often, 3: sometimes, 2: rarely, 1: never)

Table 4. Social media perception of Enterprises

\begin{tabular}{l|c}
\hline \multicolumn{1}{c|}{ Social media perception } & Percent $(\%)$ \\
\hline Quick access to information / agenda-sharing information-photos-videos & 50.00 \\
Communication & 38.00 \\
Entertainment - Magazine & 12.50 \\
News & 12.50 \\
Lingering, fill up lies, waste of time & 6.90 \\
Keeping up with the era, small world & 5.50 \\
Others & 5.50 \\
I have no idea, I don't use & 4.20 \\
Game & 1.40 \\
Total & 100.00 \\
\hline
\end{tabular}

Table 5. Social media platforms preferred by Enterprises

\begin{tabular}{|c|c|c|}
\hline Social media platforms & Person* & Percent $(\%)$ \\
\hline WhatsApp & 70 & 87.5 \\
\hline Facebook & 69 & 86.2 \\
\hline YouTube & 56 & 70.0 \\
\hline Instagram & 41 & 51.2 \\
\hline Twitter & 28 & 35.0 \\
\hline
\end{tabular}

*Calculated for users with multiple accounts

Table 6. Frequencies of Enterprises to Prefer social media in Agricultural Production

\begin{tabular}{l|c}
\hline \multicolumn{1}{c}{ Social media usage purpose } & Average $^{*}$ \\
\hline I read articles on topics that interest me & 4.13 \\
I follow the pages of the people I am interested in (what they write, the content they upload, etc.) & 4.04 \\
I look at the photos & 3.85 \\
I watch a video about agricultural production & 3.75 \\
I share the photos I like & 3.35 \\
I share videos about agricultural production that I like & 3.34 \\
I share my articles / opinions & 3.16 \\
I write comments on content (video, music, photo, opinion, text, etc.) & 3.06 \\
I participate in discussions on topics that interest me & 2.96 \\
I join groups that I like & 2.95 \\
I share photos of myself & 2.65 \\
I share my own videos & 2.58 \\
I follow the event pages & 2.46 \\
I regularly update my personal / professional information & 2.19 \\
Other (Please specify): & 0.06
\end{tabular}

"(5: Always 4: Often 3: Sometimes 2: Rarely 1: Never) 
In the study, the question "What is social media?" was asked to unveil how social media is perceived by enterprises. The answers are categorized under 9 main subtitles (Table 4). $50.00 \%$ of enterprises have defined social media as a platform where they can access information and share. Enterprises view social media as a source of information on almost every subject related to agriculture, especially field crops, animal husbandry, irrigation and agricultural struggle. $93.00 \%$ said that if innovation and technological developments take place more, they would spend more time on social media. The adoption process of innovations in rural areas is an average of 15 years (Yener, 2017). To shorten this process, social media should be used more actively in the promotion of innovations.

It has been ascertained that $90.00 \%$ of the enterprises in the study area have social media accounts. $97.00 \%$ of them have WhatsApp accounts and $96.00 \%$ Facebook accounts (Table 4). It has also been discovered that $30.00 \%$ of the enterprises have WhatsApp, Facebook, YouTube, Instagram and Twitter accounts. WhatsApp ranks first in the frequency of using social media platforms, followed by Facebook, Instagram, YouTube and Twitter. $73.00 \%$ of enterprises with social media accounts follow these platforms for more than five years, and $40.00 \%$ spend more than 7 hours a week on social media.

When looking at the frequency of agricultural actions on social media, it was found that enterprises frequently read articles on topics that interest them in agricultural production, followed the pages of those they were interested in, looked at the photographs they encountered on social media, and watched videos about agricultural production (Table 6).

In the study, it was unearthed that it is definitely simpler for enterprises to reach what they are looking for on social media than traditional media (Table 7). Because social media users create their own groups and communities, share information, buy and sell goods/services and can only do this by sending photos, videos, links. In the study, it was resolved that the brands that exist in social media and use this field effectively affect the purchasing decisions of the enterprises. Social media both create awareness about the company and the brand in agricultural marketing and creates a positive effect on consumers that support sales (Balkrishna \& Deshmukh, 2017).

Factor analysis was performed on 19 independent variables to ascertain the social media usage purposes of enterprises. According to the results of the factor analysis, 3 independent variables with an eigenvalue above one were defined as a result of the principal components analysis performed with Promax rotation. The ratio of 3 independent variables representing all variables is 79.364\%. Kaiser-Meyer-Olkin Sampling Adequacy Criterion statistic calculated over the data in the analysis was calculated above $0.6(0.892)$ and the data were found suitable for factor analysis. The resulting 3 factors were named considering the variables in which other variables have factor loads. The first variable is named "Professional Development", the second variable is "Socialization" while the third is "Communication" (Table 8).

According to the regression analyses, social media usage purposes and social media platforms used by enterprises were examined. One of the social media platforms that affect the use of social media for professional development, WhatsApp was found to be significant at $1 \%$ and YouTube at 5\% (Table 9). In other words, enterprises are in contact with groups established on WhatsApp to realize their professional development. YouTube, on the other hand, is among the resources used by enterprises in matters that interest them or in professional information they think are lacking. Research finding should be discussed related studies.

Table 7. Social Media (SM) Perspectives of Enterprises

\begin{tabular}{l|l}
\hline \multicolumn{1}{c|}{ Social media perspectives } & Avarage $^{*}$ \\
\hline I think it is easier to find the information searched in SM channels & 4.26 \\
compared to traditional media (such as newspaper, TV, radio). & 3.60 \\
Negative news/user comments I come across on social media about & 3.55 \\
goods and services affect my buying behavior. & 3.45 \\
I think an agricultural brand I see in SM is more innovative. & 3.40 \\
Comment / video / review / blog post / related article etc. for users or & \\
my friends about the agricultural information I have acquired. I share. & 3.40 \\
Promotions, advertisements and user comments in the SM are effective & \\
in trying a new brand, product or service. & 3.30 \\
I think that if one of the two competing brands in the field of agriculture & \\
is included in SM, that brand will gain a competitive advantage. & 3.06 \\
The negative news of the agricultural brand I follow, which is reflected \\
in SM, negatively affects my loyalty to the brand. \\
$\begin{array}{l}\text { Feedback from SM (review / comment / post and other types) influences } \\
\text { my decision on agricultural issues. }\end{array}$ \\
The presence of an agricultural brand in SM affects my positive attitude \\
towards that brand. & 2.95 \\
I am impressed by the posts brands make in SM. & 2.95 \\
I trust the agricultural knowledge I got from SM. & 2.64 \\
I believe that the information about agricultural products and services in \\
SM is more trustworthy than the information on mass media channels \\
(TV, radio, internet, cinema) as it is beyond the control of companies.
\end{tabular}


Table 8. Reasons for enterprises to use social media

\begin{tabular}{|c|c|c|c|c|}
\hline Factors & Scale Items & Factor Loads & Average & ariance Average \\
\hline \multirow{7}{*}{ Professional Development } & $\begin{array}{l}\text { Social media helps me develop my } \\
\text { enterprises/increase my income }\end{array}$ & 0.690 & 3.26 & \multirow{7}{*}{65,087} \\
\hline & \multirow{6}{*}{$\begin{array}{c}\text { I can be in constant communication with my } \\
\text { friends and acquaintances. } \\
\text { I can meet new people } \\
\text { I can constantly follow the current } \\
\text { developments } \\
\text { I can get easily aware of various events } \\
\text { I can consult opinions and advice on matters I } \\
\text { am curious about. } \\
\text { I can meet people who think like myself }\end{array}$} & 0.802 & 4.24 & \\
\hline & & 0.730 & 4.11 & \\
\hline & & 0.802 & 4.21 & \\
\hline & & 0.790 & 4.15 & \\
\hline & & 0.821 & 4.30 & \\
\hline & & 0.758 & 4.23 & \\
\hline \multirow{6}{*}{ Socialization } & Having fun time & 0.711 & 3.39 & \multirow{6}{*}{8,272} \\
\hline & I spend my free time & 0.812 & 3.35 & \\
\hline & I'm getting away from the stress of daily life & 0.823 & 3.36 & \\
\hline & I feel like belonging to a group & 0.520 & 3.48 & \\
\hline & $\begin{array}{l}\text { I feel more comfortable compared to face-to- } \\
\text { face communication }\end{array}$ & 0.676 & 3.08 & \\
\hline & $\begin{array}{l}\text { Not using social media is perceived as a } \\
\text { deficiency by my environment }\end{array}$ & 0.638 & 3.21 & \\
\hline \multirow{6}{*}{ Communication } & I can express my thoughts freely & 0.735 & 3.13 & \multirow{6}{*}{6,005} \\
\hline & It makes me discover my potential & 0.642 & 2.61 & \\
\hline & I can introduce myself with a different identity & 0.538 & 2.19 & \\
\hline & I think my opinions are taken into account & 0.785 & 3.13 & \\
\hline & $\begin{array}{l}\text { I believe I can make a change by expressing } \\
\text { my reactions freely }\end{array}$ & 0.748 & 2.78 & \\
\hline & $\begin{array}{c}\text { I can react to social/political issues in line with } \\
\text { my beliefs and values. }\end{array}$ & 0.861 & 2.91 & \\
\hline \multicolumn{2}{|c|}{\begin{tabular}{l|l} 
Total Value \\
Kaiser-Meyer-Olkin Sample Proficiency
\end{tabular}} & \multicolumn{3}{|r|}{$\begin{array}{c}79,364 \\
0.892\end{array}$} \\
\hline \multicolumn{2}{|l|}{ Bartlett's Test of Sphericity } & $\begin{array}{l}\text { Chi Square Value } \\
\text { Degree of Freedom } \\
\text { sig. }\end{array}$ & & $\begin{array}{c}2,138.959 \\
171 \\
0.000\end{array}$ \\
\hline
\end{tabular}

Table 9. Analysis of social media platforms that affect the use of social media for professional development

\begin{tabular}{l|ccccc}
\hline \multicolumn{1}{c}{ Social media platforms } & $\mathrm{B}$ & Std. Error & Beta & $\mathrm{t}$ & Sig. \\
\hline (Constant) & -1.719 & 0.246 & & -6.979 & 0.000 \\
Facebook & -0.019 & 0.071 & -0.029 & -.261 & 0.795 \\
Youtube & 0.221 & 0.098 & 0.288 & 2.248 & 0.028 \\
Twitter & 0.107 & 0.067 & 0.167 & 1.602 & 0.113 \\
Whatsapp & 0.293 & 0.083 & 0.486 & 3.535 & 0.001 \\
Instagram & -0.074 & 0.062 & -0.145 & -1.197 & 0.235 \\
\hline
\end{tabular}

$\mathrm{R}^{2}=47.30$ adj $\mathrm{R}^{2}=43.7 \mathrm{~F}=13.270$ Durban Watson $=1.676$

Table 10. Analysis of social media platforms affecting the use of social media for socialization purposes

\begin{tabular}{l|ccccc}
\hline \multicolumn{1}{c}{ Social media platforms } & $\mathrm{B}$ & Std. Error & Beta & $\mathrm{t}$ & Sig. \\
\hline (Constant) & -1.110 & 0.287 & & -3.866 & 0.000 \\
Facebook & 0.278 & 0.083 & 0.433 & 3.359 & 0.001 \\
Youtube & -0.188 & 0.115 & -0.244 & -1.637 & 0.106 \\
Twitter & -0.017 & 0.078 & -0.027 & -0.221 & 0.826 \\
Whatsapp & 0.047 & 0.097 & 0.077 & 0.482 & 0.632 \\
Instagram & 0.155 & 0.072 & 0.303 & 2.150 & 0.035 \\
\hline
\end{tabular}

$\mathrm{R}^{2}=28.3$ adj $\mathrm{R}^{2}=23.5 \mathrm{~F}=5.853$ Durban Watson $=2.250$

Of the social media platforms, Facebook is found to be significant at $1 \%$ and Instagram at $5 \%$, which affect the use of social media for socialization purposes (Table 10). Social media platforms are very mattering for the development of agricultural production and transfer of innovation and technological developments.

To secure the professional development of enterprises, all in the region should be included in the groups set on
WhatsApp and the necessary information should be made on the groups. On YouTube, the number of videos required for enterprises should be raised. Besides, the number of shares that will contribute to the development of enterprises on platforms used for socialization should be increased (Table 9-10). 


\section{Conclusion and Recommendations}

Of the information sources frequently utilized by enterprises during their agricultural activities, TV programs ranked first while the Internet was the second. After traditional media, social media is an innovative application and owing to its simplicity to use, it has adapted very swiftly to the rural area. The use of social media in the field of research is mostly focused on socialization, communication, and information exchange and sharing. Social media has not yet been discovered in terms of business development and opportunities as no social media-related element has been encountered in the income levels of the enterprises. While most business owners have multiple social media accounts, they do not have websites. Moreover, very few of them are planning to invest in social media in the near future. However, the time spent on the internet and social media is quite high on business basis. This reveals the need for guidance to enterprises and enterprises owners on how to benefit from social media in terms of business development and personal development. Adding this perspective to the training and support policies of the Ministry of Agriculture and Forestry for farmers will furnish positive results. In addition, informative groups should be established on WhatsApp, all enterprises in the region should be involved in these groups and necessary information should be made on these groups. The number of videos required for enterprises on YouTube should be extended, as well as the number of posts that will contribute to the professional development of enterprises on Instagram and Facebook.

$93.00 \%$ of enterprises using social media affirmed that they would allocate more time to social media if innovation and technological developments take place more. Some studies reveal that the adoption process of any innovation by agricultural enterprises is about 15 years. In this case, choosing social media platforms to integrate any innovation with the rural area will be efficient in shortening the adoption process.

In the study, it was resolved that the internet and social media usage of the enterprises located in the Selçuklu district of Konya Province is rather high. The most crucial factor is that the geographical structure of Konya province is in the form of wide plains. Owing to this geographical structure, internet service is provided without interruption. Internet infrastructure is insufficient, especially in places where the landforms are bumpy, and this situation decreases the use of the internet and social media by the users. In this respect, Konya province Selçuklu district is relatively lucky.

Social media has become an influential tool of agricultural marketing. However, using social media in agricultural marketing requires certain knowledge and experience. This awareness has not yet been built in the enterprises covered by the study. The formation of awareness should be provided by both training and social media.

\section{References}

Anonymous 2019a. The Power of social media in Agriculture: A Guide to Success in social media, http://animalagalliance.org/images//images/ upload/ Social\%20 Media\%20Manual.pdf (Accessed date: 10/02/2019).
Anonymous 2019b. Digital in 2019, https://wearesocial.com/ global-digital-report-2019 (Accessed date: 10/02/2019).

Anonymous 2019c. "Demografik Durum", http://www. konyadayatirim.gov.tr/konya.asp?SayfaID $=3 \quad$ (Accessed date: 10/02/2019).

Aoyama H. 1954. A study of stratified random sampling. Ann. Inst. Stat. Math, 6: 1-36.

Balkrishna B, Deshmukh A. 2017. "A Study on Role of Social Media in Agriculture Marketing and its Scope", Global Journal of Management and Business Research:E Marketing, Volume 17, Issue 1, Global Journals Inc., USA.

Banks S, Goodyear P, Hodgson V, McConnell D. 2003. "Introduction to the Special Issue on Advances in Research on Networked Learning." Instructoinal Science 31(1): 1-6.

Below TB, Mutabazi KD, Kirschke D, Franke C, Sieber S, Siebert R, Tscherning K. 2012. Can farmers' adaptation to climate change be explained by socio-economic household-level variables? Global Environmental Change, 22(1): 223-235.

Boz İ, Akbay C, Orhan E, Candemir S. 2004. Çiftçilerin Tarımsal Faaliyetlerde Kullandıkları Bilgi Kaynaklarının Belirlenmesi ve Tarımsal Yayım Açısından Değerlendirilmesi. Türkiye VI. Tarım Ekonomisi Kongresi, 16-18 Eylül 2014, Tokat.

Büyükbay EO, Gündüz O. 2011. An Investigation on Computer and Internet Use for Agricultural Development in Rural Areas: A Case Study for Tokat Province in Turkey. African Journal of Biotechnology, 10 (56): 11879-11886.

Carvalho L, Goodyear P. 2014. The architecture of productive learning networks. Routledge.

Cronbach LJ. 1951. Coefficient alpha and the internal structure of tests. Psychometrika. 16:297-334.

Danso-Abbeam G, Ehiakpor DS, Aidoo R. 2018. Agricultural extension and its effects on farm productivity and income: insight from Northern Ghana. Agriculture and Food Security, 7(1): $1-10$.

Dawson B, Trap RG. 2004. Basic and Clinical Biostatistics, Lange Medical Books/McGraw-Hill, Third Edition, 312.

Digital 2020. https://wearesocial-net.s3-eu-west-1.amazonaws. com/wp-content/uploads/common/reports/digital2020/digital-2020-global.pdf (Accessed date: 10/02/2021).

Dirckinck-Holmfeld L, Jones C, Lindström B. 2009. Analysing Networked Learning Practices in Higher Education and Continuing Professional Development (Technology Enhanced Learning Vol. 4). Rotterdam, The Netherlands: Sense Publishers.

Erdoğan İ. 1997. İşletmelerde Davranış, İstanbul Üniversitesi İşletme Fakültesi Yayın No: 272, İstanbul.

Everest B, Yavaş A, Tatar E, Acar I, Çakar F. 2019. Çiftçilerin Kooperatifçilik eğitimi alma isteğini etkileyen faktörler: Çanakkale ili örneği. Anadolu Tarım Bilimleri Dergisi, 34(1): 40-46.

Goodyear P, Carvalho, L. 2013. "The Analysis of Complex Learning Environments." In Rethinking Pedagogy for a Digital Age: Designing for 21st Century Learning, edited by H. Beetham and R. Sharpe, 49-63. New York, NY: Routledge.

Gujarati DN. 2009. Basic Econometrics. Tata McGraw-Hill Education.

Gül A. 1995. Sulamanın GAP Alanında Tarım Sektöründe Üretim Yapısı, Girdi Kullanımı, Verimlilik ve İşletme Gelirleri Üzerine Etkileri, Çukurova Üniversitesi Fen Bilimleri Enstitüsü Tarım Ekonomisi Anabilim Dalı, Yayınlanmamış Doktora Tezi, Adana.

Güneş T, Arıkan R. 1985. Agricultural Economics Statistics. Ankara University Faculty of Agriculture Journal, 924.

Han H, Xiong J, Zhao K. 2021. Digital inclusion in social media marketing adoption: the role of product suitability in the agriculture sector. Information Systems and e-Business Management, 1-27. 
Harniati H, Anwarudin O. 2018. The interest and action of young agricultural entrepreneur on agribusiness in Cianjur Regency, West Java. Jurnal Penyuluhan, 14(2).

Hawley JL, Hall K, Chowdhury A. 2018. Agricultural Communicators' Use of Mobile Devices and social media in USA. Rural Extension and Innovation Systems Journal, 14(1): 101

Johnson RA, Wichern DW.1992. Applied Multivariate Statistical Analysis. New Jersey, Prentice-Hall Inc, 396-397.

Kalaycı Ş. 2014. SPSS uygulamalı çok değişkenli istatistik teknikleri. Ankara: Asil Yayınları.

Kanjina S. 2021. Farmers' Use of social media and its Implications for Agricultural Extension: Evidence from Thailand. Asian Journal of Agriculture and Rural Development, 11(4): 302-310.

Kassem HS, Alotaibi BA, Muddassir M. Herab A. 2021. Factors influencing farmers' satisfaction with the quality of agricultural extension services. Evaluation and Program Planning, 85: 101912.

Kelly N, Bennett JM, Starasts A. 2017. Networked learning for agricultural extension: a framework for analysis and two cases. The Journal of Agricultural Education and Extension, 23(5): 399-414.

Khan GA, Muhammad S, Chaudhry KM, Khan MA. 2010. Present status and future preferences of electronic media as agricultural information sources by the farmers. Pakistan Journal of Agricultural Sciences, 47(2): 166-172.

Kwon O, Lee J, Jeong D, Lee JH. 2018. A Study on the Development of Fruit Tree Experience Programs Based on User Segmentation. Journal of Environmental Science International, 27(10): 865-874.

Last JM. 2001. A Dictionary of Epidemiology, Fourth Edition, Oxford University Press, 43.

Naveed MA, Anwar MA, Bano S. 2012. Information seeking by Pakistani farmers: A review of published research. Pakistan Journal of Information Management and Libraries, 13(1).

Ofori M, El-Gayar O. 2019. The State and Future of Smart Agriculture: Insights from mining social media. In 2019 IEEE International Conference on Big Data (Big Data) (pp. 51525161). IEEE.

Pradhan K, Saha A, Maity B, Ram K. 2020. Utilization Potential of Agricultural Information Sources. Journal of Plant Development Sciences Vol, 12(5): 297-301.

Preston K. 2018. How to Set. a Realistic Social Media Advertising Budget, https://www.webstrategiesinc.com/ blog/how-to-set-a-realistic-social-advertising-budget (Accessed date:10.02.2019).
Raju JK. 2016. International Journal of Engineering Sciences and Research Technology Role of Facilities in Agribusiness Supply Chain Management: A Case Study of Dry Chilli Farmers. ISSN: 2277-9655.

Raju JK. 2017. Global Journal of Engineering Science and Research Management.

Riley M, Robertson B. 2021. \# farming365-Exploring farmers' social media use and the (re) presentation of farming lives. Journal of Rural Studies, 87: 99-111.

Soylu D, Cevher N, Schirone M, Medeni T. 2016. A comparative study of information-seeking behavior and digital information needs of farmers in Turkey and Sweden. International journal of ebusiness and eGovernment studies, 8(2): 18-33.

Statista 2019. Social Media Statistics and Facts, https://www.statista.com/ topics/1164/social-networks/ (Accessed date: 10/02/2019).

Tamuliene V. 2014. Project activities in Silale District Municipality. Research For Rural Development, 2: 266.

Tekbaş N. 2014. Üniversite Öğrencilerinin Sosyal Ağları Kullanımlarına Yönelik Bir Araştırma, Journal of History School (JOHS), 7(17): 851-870

Thakur D, Chander M, Sinha SK. 2017. A scale to measure attitude of farmers towards social media use in agricultural extension. Indian Research Journal of Extension Education, 17(3): 10-15.

Tiraieyari N, Idris K, Hamzah A, Uli J. 2010. 'Importance of program development competencies for agricultural extension agents' performance in process of technology transfer." American Journal of Agricultural and Biological Sciences, 5(3): 376-379.

TÜBİSAD, 2018. Türkiye'de E-Ticaret 2017 Pazar Büyüklüğü, http://www.tubisad.org.tr/tr/images/pdf/tubisad_2018_eticaret_sunum_tr.pdf (Accesseddate: 10.02.2019).

TURKSTAT, 2019a. http://www.tuik.gov.tr/PreTablo.do?alt_ id=1028 (Accessed date: 10.02.2019).

TURKSTAT, 2019b. https://biruni.tuik.gov.tr/medas/?kn=95\& locale $=\operatorname{tr}$ (Accessed date: 08.02.2020).

TURKSTAT, 2019c. https://biruni.tuik.gov.tr/medas/?kn=65\& locale $=\operatorname{tr}$ (Accessed date: 08.02.2020).

Yamane T. 1967. Elementary Sampling TheorylTaro Yamane No. 04; QA276. 5, Y3.

Yener A. 2017. Konya İlinde Süt Sığırcılığı Yapan Aile İşletmelerinde Yeniliklerin Benimsenmesi ve Yayılmasına Etki Eden Faktörler, Selçuk Üniversitesi Fen Bilimleri Enstitüsü, Tarım ekonomisi Anabilim Dalı, Doktora Tezi, 140 sy. 